\title{
Kas-iskelet sistemi enfeksiyonlarında etken mikroorganizmalar
}

\section{Microbiological agents in musculoskeletal infections}

\author{
Mümine Nursu Şahin \\ Enfeksiyon Hastalıkları ve Klinik Mikrobiyoloji Uzmanı, \\ Sağlık Bilimleri Üniversitesi, Metin Sabancı Baltalimanı Kemik Hastalıkları Eğitim ve Araştırma Hastanesi, İstanbul
}

\begin{abstract}
Osteomiyelit ve enfeksiyöz artrit, özellikle çocukluk çağında kalıcı hasar ve deformitelere neden olabilen ve diğer yaş gruplarında da ciddi morbidite ve mortaliteye neden olan hastalıklardır. Ortopedik enfeksiyonlara neden olan mikrobiyolojik etkenler çok çeşitlidir. Hastanın yaşı, etkenin kemiğe ulaşma yolu ve altta yatan bir hastalığın varlığı gibi faktörlere bağlı olarak etkenler farklılık gösterir. Günümüzde artrit ve kırıkların tedavisinde, ortopedik implant ve protezlerin kullanılmasındaki artışa bağlı olarak protez enfeksiyonları daha sık görülmektedir. Doğru bir antimikrobiyal tedavi için mikrobiyolojik etkenlerin bilinmesi önemlidir. Tanıda kemik biyopsisi, sinoviyal sıvı ve doku kültürleri kullanılır ancak sürüntü kültürü yanıltıcı olabilir. Kültür sonucu elde edilemeyen olgularda olası etkenlerin bilinmesi ve ampirik antibiyotik tedavisinin başlanması olumlu sonuçlar verir. Etkenler genellikle bakterilerdir ve tüm yaş gruplarında en sık görülen etken Staphylococcus aureus'dur. Ancak son yıllarda Kingella kingae ve toplum kaynaklı metisiline dirençli Staphylococcus aureus (MRSA) giderek artan sıklıkta izole edilmektedir. Diyabetik ayak enfeksiyonları osteomiyelit ve doku nekrozu ile seyredebilir ve sıklıkla alt ekstremite amputasyonu ile sonuçlanır. Başlangıçta monomikrobiyal olan etkenler, ileri olgularda polimikrobiyal olur. Yumuşak doku enfeksiyonları hafif bir selülitten ölümcül olabilen nekrotizan fasiit ve gazlı gangren gibi değişik tablolarda karşımıza çıkabilir. Derlememizde kasiskelet sistemi enfeksiyonlarına neden olan etken miroorganizmalar ayrıntılarıyla ele alınacaktır.
\end{abstract}

Anahtar sözcülkler: osteomiyelit; enfeksiyöz artrit; protez enfeksiyonu; mikrobiyoloji; diyabetik ayak; nekrotizan fasiit; gazlı gangren
Osteomyelitis and infectious arthritis may lead to permanent sequels and deformities in childhood. It also causes severe morbidity and mortality in other age groups. Microbiological agents leading to orthopaedic infections are various. Aetiological agents may vary depending on the patient's age, agent's arrival path to the bone and presence of other underlying diseases. There is a recent increase in prosthetic infections due to the increase of orthopedic implant usage. The exact aetiological factor needs to be isolated and known for accurate antimicrobial treatment. Biopsy of the bone and cultures of the synovial fluid and tissues are important for the diagnosis however swab cultures could be misleading. In cases, where the aetiological agent can not be identified, it is important to estimate and initiate an empirical antibiotic therapy. The pathogenic agents are usually bacteria and the most common one in all age groups is Staphylococcus aureus. Though, in the recent years, Kingella kingae and community acquired Meticilline Resistant Staphylococcus aureus (MRSA) are more commonly isolated. Osteomyelitis and tissue necrosis are common in diabetic foot patients and it usually ends up with amputation of the lower extremity. Initially, most cases are monomicrobial but in the later stages they become polymicrobial. Soft tissue infections can be encountered through a spectrum of diseases including mild cellulitis to lethal necrotizing fasciitis or gas gangrane. In this review, we have evaluated the aetiological agents leading to infections of the skeletal system.

Key words: osteomyelitis; infectious arthritis; prosthetic infection; microbiology; diabetic foot; necrotizing fasciitis; gas gangrane

\section{ENFEKSIYÖZ ARTRIT}

Enfeksiyöz artrit, sinovya ve sinoviyal sıvının çeşitli mikroorganizmalarla enfekte olması sonucu gelişen iltihabi bir eklem hastalığıdır. Mikroorganizmaların ekleme ulaşması hematojen yayılım sonucu oluşabileceği gibi osteomiyelit komplikasyonu olarak ya da direkt inokulasyonla da görülebilir. Enfeksiyöz artrit her yaş grubunda görülebilir ve tek ya da çok eklemi tutabilir.

\section{Akut Bakteriyel Artrit}

Artritler, bakteriyel etkenlerle oluştuğunda septik, piyojenik veya süpüratif artrit adını alır. Hızlı eklem harabiyeti ve geri dönüşümsüz işlev kaybı yapabileceğinden acil durumlar olarak değerlendirilir. Septik artritler birçok bakteri tarafından oluşturulabilir (Tablo 1 ) ve bu bakterilerin türü yaşa ve bazı predispozan etmenlere göre (romatoid artrit, ileri yaş, diabetus mellutus,

- İletişim adresi: Uz. Dr. Mümine Nursu Şahin, Baltalimanı Hisar Cad. No: 62, 34470 Sarıyer, İstanbul

Tel: 0532 - 2250857 e-posta: nursusahin@gmail.com

- Geliș tarihi: 22 Mayıs $2020 \quad$ Kabul tarihi: 23 Haziran 2020 
Tablo 1. Septik artrit etkenleri ${ }^{[1.2]}$

\begin{tabular}{lc}
\hline Mikroorganizma & Sayı (n. 2302) (\%) \\
\hline Gram pozitif & \\
\hline Staphylococcus aureus & $1066(46)$ \\
Koagülaz negatif stafilokoklar & $84(4)$ \\
Streptokoklar & $512(22)$ \\
Streptococcus pyogenes & $183(8)$ \\
Streptococcus pneumoniae & $156(7)$ \\
Streptococcus agalactiae & $69(3)$ \\
Diğer streptokoklar & $104(5)$ \\
\hline Gram negatif & \\
\hline Escherichia coli & $91(4)$ \\
Haemophilus influenzae & $104(5)$ \\
Neisseria gonorrhoeae & $77(3)$ \\
Neisseria meningitidis & $28(1)$ \\
Pseudomonas aeruginosa & $36(2)$ \\
Salmonella spp. & $25(1)$ \\
\hline Diğer gram negatif basiller & $110(5)$ \\
\hline Anaerob ve diğerleri & $136(6)$ \\
\hline Polimikrobiyal & $33(1)$ \\
\hline
\end{tabular}

kronik böbrek ve karaciğer yetmezliği, kollajen vasküler hastalıklar, malignite, orak hücre (sickle cell) hastalı̆̆ı, HIV enfeksiyonu, steroidler, artroskopi, intra-artiküler enjeksiyonlar, penetre yaralanmalar, prostetik eklemler, intravenöz ilaç kullanımı, endokardit) farklılık gösterir. ${ }^{[1,2]}$

Staphylococcus aureus (S.aureus) tüm yaş gruplarında en sık görülen etkendir. Erişkinlerde yapılan farklı çalışmalarda en sık rastlanan etken \%37-65 oranında S.aureus'tur. Romatoid artritli hastalarda bu oran daha yüksektir (\%75). Daha önceden metisiline dirençli S.aureus (MRSA) ile kolonize olmuş veya herhangi bir MRSA enfeksiyonu geçirmiş kişilerde septik artrit geliştiğinde MRSA'nın görülme olasılığı daha yüksektir. Çocuklarda, geçirilen bir enfeksiyonun süpüratif komplikasyonu olarak toplum kaynaklı MRSA artritler de geliş̧ebilir. ${ }^{[3]}$ Sağlık tesisleri ile sık teması olan hastalarda vankomisin-intermediate S.aureus etken olarak rapor edilmiştir. S.aureus intravenöz ilaç bağımlılılarında artritin sık görülen nedenlerindendir. İnfantlarda Grup B streptokoklar, gram negatif basiller ve S.aureus sık görülürken, iki yaşından büyük çocuklarda S.aureus asıl etkendir. ${ }^{[1,4]}$ Öktem ve ark.'nın çalışmasında, septik artritli 13 olgunun dokuzunun kan kültürlerinde (\%46,1 S.aureus, \%15,3 Staphylococcus epidermidis, \%7,6 Staphylococcus agalacticae) ve sekizinin püy kültüründe (\%58,3 S.aureus, \%41,7 S.agalacticae) üreme olduğu görülmüştür. ${ }^{[5]}$
Haemophilus influenza (H.influenza) altı ay ile beş yaş arasında sıktır. Üst solunum yolu enfeksiyonu veya bakteremiyle seyreden otitis media sonrası gelişir. Günümüzde bu etkene karşı yaygın aşılama sonucunda sıklığı azalmıştır. Normal ağız florasında bulunan Kingella kingae, dört yaş altı çocuklarda görülen hematojen septik artritte H.influenzae'nın yerini almıştır ve sıklıkla stomatit veya üst solunum yolu enfeksiyonları ile ilişkilidir. ${ }^{[6]}$

Neisseria gonorhoeae, eskiden, olguların çoğunun 30 yaş altında olduğu, seksüel olarak aktif yetişkinlerde ve adolesanlarda görülen septik artritin başlıca etkeni iken, günümüzde mukozal gonore olgularının azalmasına bağlı olarak gonokokal artrit prevalansı da düşmüştür. Gonokokal artritler ya dissemine gonokokal enfeksiyonlar sırasında (\%42-85) ya da tenosinovit, dermatit ve poliartralji şeklinde seyreden gonokokal enfeksiyonlar esnasında oluşur. Sıklıkla monoartiküler (diz, el ve ayak bileği) nadiren oligoartiküler tutulum yapar. Kadınlarda asemptomatik olarak endoservikal bölgede bulunabildiğinden, menstruasyon, gebelik ve postpartum dönemde gelişen artritlere neden olabilir. N.meningitidis, meningokoksemiden 5-6 gün sonra artrit yapabilir. ${ }^{[7]}$ Neisseria ailesinin diğer üyeleri olan Branhamella, Kingella ve Moraxella da artrit nedeni olabilir.

Streptokoklardan, Streptococcus pyogenes ve diğer beta hemolitik streptokoklara diyabet, malignensi ve genitoüriner yapısal bozuklukları olan yetişkinlerde sık rastlanır. Streptococcus pneumoniae, hematojen septik artritlerde \%6'lık az bir oranda saptanmış olmasına rağmen orak hücreli anemisi olan çocuklarda ve alkoliklerde etken olabileceği akılda tutulmalıdır. Streptococcus suis, Çin ve Güneydoğu Asya'da domuzlarla teması olanlarda görülmüştür.

Gram negatif basiller, özellikle yenidoğanlar, yaşlılar, intravenöz ilaç bağımlıları, kronik eklem hastalıkları, immunosupresifler ve eşlik eden başka hastalıkları (üriner enfeksiyon, dekubit yarası) olan kişilerde görülür (\%5-20). E.coli, P.aeruginosa, Serratia marcescens, Klebsiella spp. ve Enterobacter spp. en sık izole edilen bakterilerdir. Çoklu ilaç direnç oranları bu bakterilerin tabloya girmesiyle artış gösterir. ${ }^{[8]} P$.aeruginosa, intravenöz ilaç kullananlarda önemli bir patojendir ve özellikle simfisis pubis, sternoklavikuler, sternokondral ve sakroiliak gibi fibrokartilajinoz eklemlere afinitesi vardır. Çocukluk çağında Salmonella artritleri görülse de salmonella osteomiyelitlerinin aksine bunların orak hücreli anemi ile bir bağlantısı yoktur. ${ }^{[2]}$

Anaerobik bakteriler nadiren ve travmatik yaralanmalar sonucu etken olabilir. Bacteroides spp. çok nadirdir. Çocuklarda en sık rastlanan anaerob patojen Clostridium spp.'dir. 
Enfekte eklemlerden tespit edilen diğer bakteriler Corynebacterium spp., Listeria monocytogenes, Brucella spp., Mycoplasma hominis ve Ureaplasma urealyticum'dur. Kedi ve köpek ısırıklarından sonra komşuluk yoluyla gelişen septik artritlerde Pasteurella multocida ve Capnocytophaga spp., insan ısırıklarından sonraysa Eikenalla corrodens ve Fusobacterium nucleatum görülebilir ve en sık metakarpofalengeal eklemler tutulur. Tavşan ısırığı sonrası gelişen artritde Streptobasillus moniliformis kan ve eklem sıvısında üretilmiştir. Diken batması ile oluşan artritlerde en sık üretilen etken Pantoea agglomerans'tır. Brucella artriti, hem akut hem kronik seyir gösterebilir ve en sık sakroiliak eklemi tutar. Septik artritin bazı klinik/epidemiyolojik özellikleri ve etken bakteriler Tablo 2'de listelenmiştir. ${ }^{[1]}$

\section{Kronik Enfeksiyöz Artrit}

Genellikle monoartiküler, daha az sıklıkla oligoartikülerdir. Çok sayıda mikroorganizma kronik enfeksiyöz artrite neden olabilir (Tablo 3). Çoğunlukla etkenler mikobakteriler ve mantarlardır. Bakteriyel olarak bazen B.burgdorferi (Lyme hastalığı, kene ısırığı ile bulaşan bir spirokettir, poliartiküler tutulum yapar ve genellikle büyük eklemleri tutar.), Tropheryma whipplei (Whipple hastalığı), Treponema pallidum (Sifilis) ve Nocardia etken olabilir. Parazit olarak çeşitli helmint ve flarialara bağlı gelişen artritler vardır, nadiren tanımlanır, parazitler gösterilebilir ancak artrit genellikle otoimmun oluşur. ${ }^{[1]}$

Tablo 2. Septik artritte klinik/epidemiyolojik özellikler ve etken bakteriler ${ }^{[1]}$

\begin{tabular}{|c|c|}
\hline Klinik/epidemiyolojik özellik & Etyolojik ajan \\
\hline Romatoid artrit & Staphylococcus aureus \\
\hline İntravenöz ilaç kullanımı & S.aureus, Pseudomonas aeruginosa \\
\hline Diyabet, malignensi & S.aureus, Group B streptococci \\
\hline İmmunosuprese hastalar & $\begin{array}{l}\text { S.aureus, streptokoklar, enterik gram negatif basiller, } \\
\text { Listeria monocytogenes }\end{array}$ \\
\hline Yenidoğanlar, dört yaşından küçük çocuklar & Gram negatif basiller, Kingella kingae \\
\hline Genç erişkinler, menstruasyon, gebelik, ilişkili deri lezyonları & Neisseria gonorrhoeae \\
\hline Fibrokartilajinoz eklemler (örn., Simfisis pubis) & S.aureus, P.aeruginosa \\
\hline Kedi veya köpek ısırığı & Pasteurella multocida, Capnocytophaga spp., anaeroblar \\
\hline İnsan ısırığı & $\begin{array}{l}\text { Eikenella corrodens, anaeroblar, diğer ağız florası } \\
\text { (örn. Viridans streptokoklar) }\end{array}$ \\
\hline Tavşan ısırı̆̆ı & Streptobacillus moniliformis \\
\hline Postpartum kadın & Mycoplasm hominis, Ureaplasma urealyticum \\
\hline $\begin{array}{l}\text { Pastörize edilmemiş ürünlerin tüketildiği endemik bölgelerde } \\
\text { yaşayanlar veya seyahat edenler }\end{array}$ & Brucella spp. \\
\hline Güneydoğu Asya'da yaşyanlar veya seyahat edenler & Burkholderia pseudomallei (Melioidosis), Streptococcus suis \\
\hline Diken batması & Pantoea agglomerans, Nocardia spp. \\
\hline
\end{tabular}

Tablo 3. Kronik monoartiküler veya oligoartiküler artrit etkenleri ${ }^{[1]}$

\begin{tabular}{lll}
\hline Bakteriler & Mikobakteriler & Mantarlar \\
\hline Borrelia burgdorferi & M.tuberculosis & Candida spp. \\
Tropheremawhippelli & M.kansasii & Cryptococcus neoformans \\
Treponema pallidum & M.marinum & Blastomyces dermatitidis \\
Nocardia spp. & M.avium-intracellulare complex & Coccidioides immitis \\
Parazitler & M.terrae & Paracoccidioides brasilensis, Sporothrix schenckii \\
Helmintler & M.fortuitum, M.chelonae, M.abscessus & Aspergillus spp. \\
Flarialar & M.haemophlium & Scedosporium, Fusarium \\
& M.leprae & \\
\hline
\end{tabular}




\section{Mikobakteriyel Artrit}

Genellikle Mycobacterium tuberculosis dışındaki Mycobacterium spp. etkendir ve monoartikülerdir. Mycobacterium tuberculosis daha çok osteomiyelit etkeniyken, artritlerde M.avium intracellulare, M.kansasii, M.marinum en sık gözlenen etkenlerdir. Ayrıca yapıIan çalışmalarda M.terrae, M.chlonae, M.fortuitum ve M.abscessus ile oluşan kronik monoartrikülar artritler gösterilmiştir. Kadınlarda, 65 yaş üstünde, endemik bölgelerden göç edenlerde, sosyoekonomisi kötü olanlarda, alkol tüketenlerde, debil hastalarda, intravenöz ilaç kullananlarda, kortikosteroidler gibi immunosupresif ilaç kullananlarda ve HIV enfeksiyonunda tüberküloz artrit riski yüksektir. M.avium'a özellikle balıkçılarda rastlanır. M.tuberculosis artriti pulmoner tüberkülozdan hematojen yolla oluşurken (basil yıllarca eklemde sessiz olarak kalabilir) tipik olarak diz, kalça ve ayak bileğini tutar. Nontüberküloz mikobakteri artritleri direkt inokulasyon ile oluşurken, sıklıkla el ve el bileğinin küçük eklemlerini tutar; eklemle birlikte tendon kıIıfı da tutulabilir. ${ }^{[1]}$ Hogan ve ark. yaptıkları çalışmada mikobaktreriyal artritlerde nontüberküloz mikobakterilerin ve özellikle M.avium'un yerini koruduğunu vurgulamıştır. ${ }^{[9]}$ Mycobacterium leprae (Hansen hastalığı) otoimmun mekanizma ile artrite neden olabileceği gibi Charcot eklemi ile de ilişkili olabilir. Lepramatoz lepra el bileği, metakarpal kemikler ve elin küçük eklemlerinde simetrik poliartrit yapar. ${ }^{[1]}$

\section{Fungal Artrit}

Genellikle monoartikülerdir. İmmunosuprese ya da kronik hastalığı olanlarda görülme sıklığı artmakla beraber sağlıklı konaklarda da oluşabilir. Endemik bölgelerdeki sağlıklı konaklarda Blastomyces dermatidis, Coccidioides spp., Paracoccidioides brasilensis ve Sporothrix schenckii görülürken, immunosuprese konaklarda (uzun süre hastanade yatış, uzamış antibiyotik kullanımı, diabetes mellitus, immunosupresif tedavi, malignensi, prematüre doğum, i.v. ilaç bağımlılığı, santral kateter vb.) Candida spp. (özellikle C.albicans), Cryptococcus ve Aspergillus daha sık görülmektedir. Fusarium hem sağlıklı hem de immunosuprese konakta artrit yaparken, Histoplasma capsulatum ise çok nadir olarak fungal artrit nedenidir. Sağlam konakta mantarlar ekleme ya direkt travma ve yaralanma ile ya da yabancı cisim penetrasyonu ile ulaşırken, immunosuprese grupta hem penetran yaralanmalar hem de hematojen yayılım ile yerleşir. S. schenckii ise diken batması ya da topraktan bulaşır. ${ }^{[1,10]}$

\section{Viral Artrit}

Sistemik viral bir hastalığın seyri sırasında akut olarak gelişir ve genellikle poliartiküler tutulum gösterir. Virüs'ün doğrudan sinovyayı mı enfekte ettiği yoksa artritin immun mekanizmalara mı bağlı geliştiği henüz tam anlaşılamamıştır. Human Parvovirüs B19, Rubella, Hepatit B virüs, Hepatit C virüs, HIV-1, Human T cell Leukemia virüs-1 (HTLV-1) ve bazı alfa virüs enfeksiyonları viral artritin sık geliştiği enfeksiyonlardır (Tablo 4). ${ }^{[1]}$

Human Parvovirüs B19, özellikle çocuklarda olmak üzere en sık görülen virüslerdir. Proksimal interfalengeal ve metakarpofalengeal eklemlerde simetrik poliartiküler tutulum yapar. Rubella, çocukluk çağı aşılamalarının yaygın yapılmadığı ülkelerde genellikle erişkinlerde görülen viral artritlere neden olur. En sık elin küçük eklemleri tutulur. Hepatit B akut enfeksiyonunun prodromal döneminde simetrik, tipik olarak el, el bilği, diz ve ayak bileğini tutan poliartritler yapar. Hepatit C'ye bağlı artritler daha nadirdir ve genellikle otoimmümdir. HIV-1 ve Human T cell Leukemia virüs-1 (HTLV-1) kronik persistant oligoartrit ile seyreder. Alfa virüs artritleri örneğin Chikungunya ateşi artropodlar (sinek vb.) aracılığı ile oluşur ve simetrik olarak büyük eklemleri tutan poliartritler yapar. Shmagel ve ark. artriti olan 9483 olguda Herpes Simplex Virus 1 ve 2 (HSV 1, HSV 2) ile Human Papilloma Virüsünü (HPV) araştırmışlar ve HSV2 ile HPV'un artritlerde etken olabileceğini vurgulamışlardır. ${ }^{[11]}$

\section{Reaktif Artrit}

Enfeksiyon sonrasında genellikle 1-4 hafta sonra ortaya çıkan akut, steril ve asimetrik poliartiküler tutulum yapan eklem enflamasyonudur. Birçok mikroorganizma reaktif artrite neden olmakla birlikte olguların bir kısmında etken bilinmemektedir (Tablo 5). Özellikle enterik (Shigella flexneri, Campylobacter jejuni, Salmonella typhimurim, Yersinia spp.), ürogenital (Clamydia trachomatis, Ureoplasma urealyticum) ve orofarengeal (Beta hemolitik streptokoklar, Clamydia spp.)

Tablo 4. Artritlerle ilişkili olabilen virüsler ${ }^{[1]}$

\begin{tabular}{ll}
\hline DNA virüsleri & RNA virüsleri \\
\hline Small pox & Mumps \\
Vaccinia* & Rubeola* \\
Adenovirus* & İnfluenza* \\
Varicella* & Echovirus* \\
Epstein-Bar virüs* & Alfavirus (Chikungunya, Sindbis, Ross River) \\
Cytomegalovirus* & Rubella \\
Parvovirus B19 & Lymphocytic choriomeningitis virüs \\
Hepatitis B & Hepatit C \\
& Human T cell Leukemia virüs-1 \\
& HIV-1 \\
\hline${ }^{*}$ Nadiren neden olanlar &
\end{tabular}


Tablo 5. Reaktif artrite neden olabilen enfeksiyonlar ve etkenleri ${ }^{[12]}$

Genitoüriner enfeksiyonlar
Clamydia trachomatis
Ureoplasma urealyticum
Neisseria gonorrhoeae

Gastrointestinal enfeksiyonlar
Shigella spp. (S.flexneri 1b ve $2 \mathrm{a}$ )
Salmonella spp. (S.thypimurium)
Campylobacter jejuni
Yersinia spp. (Y.enterocolitica Tip 3 ve Tip 9)

Clamydia trachomatis

Ureoplasma urealyticum

Yersinia spp. (Y.enterocolitica Tip 3 ve Tip 9)
Orofarengeal enfeksiyonlar

Beta hemolitik streptokoklar

Clamydia pneumoniae

Clamydia trachomatis
Diğer (nadiren)

Brucella spp.

Blastocystis hominis

Clostridium difficile

Borrelia burgdorferi

Clamydia psittaci enfeksiyonlarda rol oynayan mikroorganizmalar sıklıkla reaktif artrite yol açar. Bunların dışında BCG, Bacillus cereus, E.coli, Helicobacter pylori, Hafnia alveii, Lactobacillus, N. Meningitidis, Pseudomonas, Strongyloides stercoralis, Taenia saginata, Giardia lamblia, Ascaris lunbricoides ve filariasis etkenleri reaktif artrit yapabilir. ${ }^{[12]}$

\section{Septik Bursit}

Sıklıkla travma sonrası veya intrabursal kortikosteroid enjeksiyonundan sonra gelişir. Etkenlerin \%80'ini S.aureus, geri kalanını Streptococcus spp., gram negatif bakteriler, mikobacteriler ve mantarlar oluşturur. Genellikle olekronon, prepatellar veya infrapatellar bölgeler etkilenir. ${ }^{[1]}$

\section{OSTEOMIYELIT}

Osteomiyelit, mikroorganizmaların neden olduğu kemiğin enfeksiyöz bir hastalığıdır. En sık karşılaşılan mikroorganizmalar S.aureus, koagülaz-negatif stafilokoklar, gram negatif basiller ve eskiden peptostreptokoklar olarak adlandırılan Finegoldia spp.'dir. S.aureus, kemik matriksinde bulunan fibronektin, laminin, kollagen veya siyaloglikoproteine yüksek afinite gösteren adezinleri sayesinde hastalığa neden olan en sık mikroorganizmadır (Tablo 6). ${ }^{[13]}$ Çiftdoğan ve ark.'nın yaptığı çok merkezli bir çalışmanın sonucunda en sık izole edilen etken S.aureus (\%63) olarak saptanırken, bunu sırasıyla Kingella kingae (\%15), S.pyogenes (\%9) ve diğerleri (\%13) izlemiş̧tir. ${ }^{[14]}$

Osteomiyelite neden olan etkenler, mikroorganizmaların kemiğe ulaşma yoluna (hematojen, direkt inokulasyon, komşuluk), vasküler yetmezlik olup olmamasına, yaşa, hazırlayıcı faktörlere ve tutulan kemiğe göre bazı farklılıklar göstermektedir (Tablo 7). ${ }^{[13,15-17]}$

\section{Hematojen Osteomiyelit}

Hematojen osteomiyelitlerde yayılım uzaktaki bir enfeksiyon odağından bakteriyemi veya sepsis sonucu
Tablo 6. Osteomiyelit etkenleri ${ }^{[13]}$

\begin{tabular}{l}
\hline Sık karşılaşılan etkenler $(>50)$ \\
\hline Stapylococcus aureus \\
Coagulase-negative stapylococci \\
\hline Daha az sıklıkla karşılaşılan etkenler $(>25)$ \\
\hline Streptococci \\
Enterococci \\
Pseudomonas spp. \\
Enterobacter spp. \\
Proteus spp. \\
Escherichia coli \\
Klebsiella spp. \\
Serratia spp. \\
Anaeroblar \\
(Finegoldia spp., Clostridium spp., Bacteroides flagiles group) \\
\hline Nadir karşılaşılan etkenler $(<5)$ \\
\hline Mycobacteriun avium complex \\
Hızlı üreyen mikobakteriler \\
Dimorfik mantarlar \\
Candida spp. \\
Aspergillus spp. \\
Mycoplasma spp. \\
Tropheryma whipplei \\
Brucella spp. \\
Salmonella spp. \\
Actinomyces
\end{tabular}

oluşur. Hematojen osteomiyelitlerde en yaygın olarak izole edilen mikroorganizma S.aureus olmakla beraber S.pneumoniae da sık görülür. ${ }^{[13]}$ Primer hematojen osteomiyelit infant ve çocukların hastalığıdır ama erişkinlerde de rastlanabilir. Yenidoğan ve bir yaş altında Grup B streptokoklar (S.agalactiae), S.aureus, E.coli ve bir yaşından büyük çocuklarda S.aureus, S.pyogenes, $H$.influenzae sık görülen etkenlerdir. Yenidoğanlarda hematojen osteomiyelit özellikle kalıcı venöz kateterlerden kaynaklanır ve etken yenidoğan sepsisinden sorumlu olan grup B streptokoklardır. H.influenza 1-4 yaş arası görülmekle birlikte, yaygın aşılama uygulamaları neticesinde giderek azalmaktadır. Yapılan bir çalışmada, orofarengeal floranın bir üyesi olan Kingella 
Tablo 7. Osteomiyelit etkenleri ve dağılımını etkileyen faktörler ${ }^{[13]}$

\begin{tabular}{llll}
\hline & Hematojen & Nonhematojen & Vasküler yetmezliğe bağlı \\
& osteomiyelit & osteomiyelit & osteomiyelit \\
\hline Etken & Genellikle monomikrobiyal & Genellikle polimikrobiyal & Polimikrobiyal olabilir \\
& S.aureus & S.aureus \\
& Gram negatif basiller & Gram negatif basiller & S.epidermidis \\
& (E.coli, Klebsiella, Salmonella, & Snaerob bakteriler & Streptokoklar \\
& Proteus, Pseudomonas) & & Gram negatif basiller \\
& & & Anaerob bakteriler \\
& & & Diabetes mellitus \\
& Bakteriyemi & Direk inokulasyon & Periferik damar hastalıkları \\
& Sepsis & Açık kırık, & \\
& & Cerrahi redüksiyon ve internal fiksasyon & \\
& & Nosokomial & \\
& & Yakın komşuluk & \\
& & Yumuşak doku enfeksiyonu & \\
& & Dekubit ülseri & \\
& & Sellülit & Ayak \\
\hline Tutulan kemikler faktör & Uzun kemikler & Femur, tibia & \\
& Vertebra & Kafatası, mandibula & \\
\hline
\end{tabular}

kingae'nın 6-48 aylık çocuk osteomiyelitlerinde sık görülmeye başladığı bildirilmiştir. Bartonella henselae ve Borrelia burgdorferi de izole edilen etkenler arasında yer alır. Anaerob osteomiyelitler ise çocukluk çağında nadir görülen etkenlerdir. ${ }^{[18,19]}$ Çocuk yaş gruplarına göre osteomiyelit etkenleri Tablo 8'de verilmiştir. Çocuklarda, toplum kaynaklı MRSA'lara bağlı uzun kemik osteomiyeliti ve diskiti görülme sıklığı artmaktadır. Toplum kaynaklı MRSA kökenlerinde, bir cins sitokin olan Panto-Valentine lökosidin (PVL) bulunmuştur ve çocuk osteomiyelitlerinde, PVL-pozitif S.aureus'ların, PVL-negatif S.aureus'lara göre multifokal ve daha agresif olduğu gösterilmiştir. ${ }^{[20]}$ Erişkinlerde ise sekonder hematojen osteomiyelit daha azdır ve en sık görülen etken S.aureus'tur. Genellikle çocukluk çağında geçirilen osteomiyelitler sırasında osteoblastlar tarafından tutulan S.aureus'lar, dormant-sessiz olarak canlı kalabilmekte, zamanla fenotipik olarak değişebilmekte ve

Tablo 8. Çocuk yaş gruplarına göre osteomiyelit etkenleri EKMUD[13]

\begin{tabular}{ccc}
\hline 1 yaş altı & $1-16$ yaş & 16 yaş üstü \\
\hline Grup B & S.aureus & S.epidermidis \\
streptokoklar & S.pyogenes & S.aureus \\
S.aureus & H.influenza & P.aeruginosa \\
E.coli & & S.marcescens \\
& & E.coli \\
\hline
\end{tabular}

osteomiyelit nükslerine neden olabilmektedir. Gram negatif basiller de sık görülen etkenlerdendir ve E.coli, Candida spp. ve P.aeruginosa intravenöz ilaç bağımIılarında en sık karşılaşılan mikroorganizmalardır. Hematojen osteomiyelit genellikle monobakteriyeldir; uzun kemik ve vertebraları tutar. ${ }^{[13,15,18]}$

\section{Nonhematojen Osteomiyelit}

Nonhematojen osteomiyelitler, cerrahi ve travma sonrası mikroorganizmaların kemiğe doğrudan inokulasyonuyla (perioperatif-intraoperatif işlemler sırasında nosokomial kontaminasyon, ponksiyon, eklem içi enjeksiyon, açık kırık, cerrahi redüksiyon ve kırığın internal tespiti, protezler, ısırık yaraları) ya da yakındaki yumuşak doku (sellülit, dekubit yaraları) ve ekleme ait bir enfeksiyon odağından komşuluk yoluyla oluşur. S.aureus en sık etkendir. Gram negatif basiller ve anaeroblar da görülür. Komşuluk yolu ile gelişen osteomiyelitler genellikle polimikrobiyaldir. Uzun kemikleri, mandibulayı ve kafatasını tutar. ${ }^{[13,15,18]}$ Fily ve ark., Ortadoğu savaşında yaralananlarda gelişen posttravmatik osteomiyelit olgularında (n: 727) sırasıyla Enterobacteriaceae (\%57,4), S.aureus (\%26,3), P.aeruginosa $(\% 13,5)$, ve A.baumani $(\% 2,8)$ üretmişlerdir. ${ }^{[21]}$

\section{Vasküler Yetmezliğe Bağlı Osteomiyelit}

Vasküler yetmezliğe bağlı osteomiyelitlerin majör nedeni diyabetes mellitustur. Koagülaz pozitif ve negatif stafilokoklar, streptokoklar, enterokoklar, gram negatif basiller ve anaeroblar en sık izole edilen etkenlerdir 
ve polimikrobiyal olabilir. Genellikle ayağın ufak bir travmasından sonra komşuluk yoluyla oluşur ve ayağın küçük kemiklerini tutar. ${ }^{[13,15,18]}$

\section{Kontamine Açık Kırık Osteomiyeliti}

Kontamine açık kırık osteomiyelitinde en sık görülen iki etken stafilokoklar ve Gram-negatif basillerdir. Nadiren enterokoklar, mantarlar ve atipik mikobakteriler görülebilir. Patojenler, normal deri florası, kontamine toprak ve nosokomiyal etkenler olabilir. ${ }^{13,22]}$

\section{Kapalı Kırık Osteomiyeliti}

Kapalı kırık osteomiyeliti, internal tespitten sonra gelişen implant ilişkili osteomiyelitlerdir ve en sık görülen etken S.aureus'tur. Hem polimikrobiyal hem de monobakteriyel üreme olan 180 olguyu içeren bir çalışmada S.aureus \%42, koagülaz negatif stafilokoklar \%18, enterik gram negatif basiller \%30, psödomonaslar \%14, enterokoklar \%3, anaeroblar \%4 oranında izole edilirken, streptokok ve mantarlara hiç rastlanmamıştır. ${ }^{[23]}$

\section{Kronik Osteomiyelit}

Kronik osteomiyelitler yabancı cisim varlı̆̆ı, kemik nekrozu, yoğun kontaminasyon, yavaş metabolik hızı olan bakterilerle enfeksiyon, implantın neden olduğu konak defansındaki defekt, osteoliz gibi kemiğe ait lokal faktörler ve diyabet, renal-hepatik yetmezlik, malignensi, immunosupresyon, periferik damar hastalıkları, obezite, sigara kullanımı gibi genel faktörler sonucu oluşur. Kronik osteomiyelit olgularında klinik duruma göre en sık karşılaşılan mikroorganizmalar Tablo 9'da belirtilmiştir. ${ }^{[15,18]}$

Çocuklarda görülen kronik hematojen osteomiyelite genellikle gelişmekte olan ülkelerde rastlanır ve bu çocuklar geçirdikleri birçok enfeksiyonda antibiyotik kullanmamışlardır. Yapılan bir çalışmada da, kronik hematojen osteomiyeliti olan 167 çocuktan izole edilen mikroorganizmalar sırasıyla S.aureus (\%2), E.coli (\%2), Streptokoklar (\%2), Pseudomonas (\%2), Basillus subtilis (\%1), Proteus (\%1) ve üretilemeyen (\%29) şeklinde bulunmuştur.

Erişkinlerde görülen kronik hematojen osteomiyelitte ana etken S.aureus'tur. İlaveten Brucella spp. ve M.tuberculosis spesifik etkenler olarak görülebilir. ${ }^{[23]}$

\section{Vertebra Osteomiyeliti}

Vertebra osteomiyelitinde (Spondilodiskit) S.aureus ve koagülaz negatif stafilokoklar en yaygın mikroorganizmalardır ve hematojen kaynaklıdır. Bazen beraberinde

Tablo 9. Kronik osteomiyelitte klinik duruma göre sorumlu etkenler ${ }^{[15,18]}$

\begin{tabular}{ll}
\hline Klinik & Mikroorganizma \\
\hline Osteomiyelitin herhangi bir tipinde sık görülen etken & S.aureus (metisilin duyarlı veya dirençli) \\
\hline Yabancı cisim ilişkili enfeksiyon & Koagülaz negatif stafilokok veya Propionibacterium spp. \\
\hline Nosokomiyal enfeksiyon & Enterobateriaceae, P.aeruginosa, Candida \\
\hline Diyabetik ayak lezyonları ve dekübit ülserleri & $\begin{array}{l}\text { Streptokok ve/veya anaerob bakteriler Enterobateriaceae, } \\
\text { P.aeruginosa, Candida }\end{array}$ \\
\hline Orak hücreli anemi & Salmonella spp. veya S.pneumoniae \\
\hline HIV enfeksiyonu & B.henselae, B.quintana \\
\hline Insan veya hayvan ısırıkları & P.multocida veya Eikenalla corrodens \\
\hline İmmun yetmezlikli olgular & Aspergillus spp., C.albicans veya Mycobacteria spp. \\
\hline Tüerkülozun sık gözlendiği toplumlar & M.tuberculosis \\
\hline Sayılan patojenlerin endemik olduğu alanlar & $\begin{array}{l}\text { Brucella spp., C.burnetti, bazı coğrafik bölgelerde sık görülen } \\
\text { mantarlar (histoplazma vb.) }\end{array}$ \\
\hline Eroin alışkanlı̆̆ı & S.aureus \\
\hline Hemodiyaliz & S.aureus \\
\hline
\end{tabular}


psoas absesi de olabilir. Primer odak deri, yumuşak doku, genitoüriner yol, enfektif endokardit, i.v. kateter, i.v. ilaç bağımlılığı ve solunum yolları olabilirya da bakteriler, cerrahi sırasında disk ve komşu vertebralara direkt inokule olabilir. M.tuberculosis en sık torokal vertebraları tutar. Endemik bölgelerde Brucella spondilodiskitleri fazladır. Gram negatif aerobik bakterilerin ve Candida spp.'nin ve P.auriginosa'nın neden olduğu vertebra enfeksiyonları i.v. ilaç bağımlılarında, immunosupresif hastalarda ve postoperatif hastalarda yaygındır. ${ }^{[13]}$

\section{Tüberküloz Osteomiyelit}

Tüberküloz osteomiyelitte, etken M.tuberculosis ise genellikle pulmomer kaynaklıdır ve sıklıkla vertebra veya paraartiküler bölgeyi tutar. Pott hastalığı olarak bilinen vertebral osteomiyelit, M.tuberculosis' in en yaygın osteoartiküler bulgusudur. Nontüberküloz mikobakteriler (Mycobacterium marinum, Mycobacterium avium-intracelIulare, Mycobacterium fortuitum, Mycobacterium chelonae, Mycobacterium kansasii ve Mycobacterium xenopi) tarafindan da oluşturulan osteomiyelitler genellikle immunosupresiflerde, cerrahi veya travmaya bağlı kontamine olan yaralardan sonra disemine enfeksiyonlar şeklinde görülür. İnterferon gamma veya interlökin-12 defisiti olan hastalarda nontüberküloz mikobakterilerle oluşan osteomiyelitler gösterilmiştir. Bacille Calmette Guerin (BCG) ile aşılanma sonrası ve intravesiküler BCG uygulamasından sonra Mycobacterium bovis'e bağlı dissemine osteoartiküler enfeksiyonlar rapor edilmiştir. ${ }^{[13]}$

\section{Fungal Osteomiyelit}

Fungal osteomiyelitler sık görülmez. İmmunosupresifler, mantar enfeksiyonlarının endemik olduğu bölgelerde bulunanlar ve diyabeti olanlar risk altındadır. Etkenler blastomycosis, dissemine coccidioidomycosis, ekstrakutaneoz sprotrichosis, cryptococcosis, candidiasis ve aspergillosis'dir. Genellikle hematojen yolla gelişir, soğuk abseler ve bu abselere komşu kemiklerde litik lezyonlar oluşturur. Kontamine yaradan travmatik olarak gelişen osteomiyelitlerde ise Pseudallescheria boydii, Scedosporium prolificans ve Fusarium spp. görülebilir. ${ }^{[10,13]}$

\section{Anaerob Bakteri Osteomiyeliti}

Anaerob bakteri osteomiyelitinin nadir olmakla birlikte olabileceği unutulmamalıdır. Anaerob osteomiyelitler vücudun başka bir bölgesindeki anaerobik enfeksiyona ait aynı etken ile meydana gelir. Örneğin abdominal sepsis, dekubitis ülseri, ısırık, kafatası ve yüz kemiği osteomiyeliti, kronik ayak yarası, kötü kokulu eksuda varlığı, smear'de bakteri varlığına rağmen kültürde üreme olmaması gibi durumlarda anaerob bakteriler etken olarak karşımıza çıkar. Bacteroides fragilis grubunun üyeleri olan Prevotella ve Porphyromonas spp. kafatası ve ısırık hadiselerinden izole edilirken, uzun kemik anaerob enfeksiyonlarında bunlara ilaveten Fusobacterium spp. izole edilir. ${ }^{[13,24]}$

\section{SAPHO (Sinovit, Akne, Pustulosis, Hiperostosis, Osteomiyelit)}

SAPHO'nun nedeni bilinmemektedir ve biyopsi örneklerinin kültüründe bakteri, mantar ve mikobakteri üretilememiştir. Özellikle çocuklarda göğüs kemikleri, pelvis ve vertebrada kronik rekürren multifokal osteomiyelit yapar. ${ }^{[13,25]}$

\section{Osteitis Pubis}

Osteitis Pubis, simfisis pubisin enfeksiyonudur, ürolojik ve jinekolojik cerrahi girişimlerden sonra ortaya çıkar ve S.aureus, Enterococcus spp., E.coli, Pseudomonas spp. ve Proteus spp. en sık görülen etkenlerdir. ${ }^{[13,26]}$

\section{Klavikula Osteomiyeliti}

Klavikula osteomiyeliti, boyun cerrahisi ve subklavien ven kateterizasyonundan sonra gelişir. S.aureus en sık görülen mikroorganizmadır. Gram-negatif bakteriler, Coccidiodes spp. ve M.tuberculosis de görülebilir. ${ }^{[13]}$

\section{Sakroiliak Osteomiyelit}

Sakroiliak osteomiyelitte en sık etken S.aureus'tur. Nadiren ve bakteremi sonucu gelişir, bu durumda endokardit akılda tutulmalıdır. Kalıcı kateter kullananlar ve i.v. ilaç bağımlıları risk altındadır. Brucella spp., kronik tek taraflı sakroiliak enfeksiyon yapabilir. ${ }^{[13]}$

\section{Hemodiyalize Bağlı Osteomiyelit}

Hemodiyalize bağı osteomiyelit hastalarında, arteriovenöz fistül ve diyaliz kateterlerinde S.aureus kolonizasyonunun oluşması nedeni ile hematojen yolla vertebral osteomiyelit gelişme riski yüksektir. Ayrıca diabetes mellitus ve periferik venöz hastalıkların eşlik ettiği durumlarda komşuluk yoluyla ekstremitelerde de osteomiyelit gelişebilir. ${ }^{[13]}$

\section{HIV (Human Immunodeficiency Virus)}

HIV ile enfekte hastalar immunosupresif olmalarına ve birçok firsatçı mikroorganizmayla karşılaşmalarına rağmen bu hastalarda osteomiyelit nadir gelişir ancak diyabet, i.v. madde bağımlılı̆ıı, tüberküloz gibi eşlik eden hastalıkları varsa osteomiyelit gelişmesi kolaylaşır. Etken sıklıkla S.aureus'dur. HIV hastalarında Bartonella henselae ve Bartonella quintana bildirilen etkenler arasındadır. ${ }^{[18]}$ 


\section{Orak Hücreli Anemi}

Orak hücreli anemide, hastaların çoğu çocuktur ve en sık görülen etken Salmonella spp. ve S.aureus'tur. Fransızların yaptığı orak hücreli anemisi olan 299 olguluk çalışmada \%12 oranında akut, multifokal, uzun kemik osteomiyeliti geliştiği gösterilmiştir. ${ }^{[13]}$

\section{Gaucher's Hastalığı}

Gaucher's hastalığında, tipik olarak tibia tutulur ve biyopsi yapılan bölgede akut osteomiyelit gelişebileceği gibi dolaylı yoldan da akut osteomiyelit gelişebilir. ${ }^{[13]}$

\section{İntravenöz İlaç Bağımlılığı}

İntravenöz ilaç bağımlılarında, hematojen ve komşuluk yoluyla osteomiyelit gelişir ve sternoklavikuler, sternokondral, sakroiliak ve simfisis pubis gibi bölgelerde yerleşir. Etkenler genellikle S.aureus, gram negatif çomaklar, Pseudomonas spp. ve Candida spp.'dir. Bu grupta M.tuberkulosis vertebra osteomiyeliti yapar. ${ }^{[13]}$ Wylie ve ark.'nın eroin bağımlılarında yaptıkları çalışmada Stapylococcus spp., Streptocoocus spp., Bacillus spp., Serratia spp. Provetella ve Eikenalla (normal ağız florası elemanıdır ve enjeksiyondan önce derinin veya iğne ucunun yalanmasına bağı olarak osteomiyelite neden olur) izole etmişlerdir. ${ }^{[27]}$

\section{Brodie Absesi}

Brodie abseleri, sıklıkla tibianın distal bölgesini tutan kemiğin kronik lokalize abseleridir ve kültür negatif olabilir. En sık S.aureus ile oluşur. ${ }^{13]}$

\section{PROTEZ ENFEKSIYONLARI}

Protez enfeksiyonuna neden olan mikroorganizmaların genel özelliği yabancı cisimlere yapışabilmeleridir. Protez üzerinde oluşan biyofilm tabakası mikroorganizmaların tutunmasını kolaylaştırarak, antibiyotiklerin bölgeye ulaşmasını engelleyerek ve konağın savunma mekanizmalarını bloke ederek protez enfeksiyonunun oluşumunda önemli rol oynar. ${ }^{[28,29]}$

Protez enfeksiyonları etkenlerinin sıklığı yayınlara göre farklılıklar göstermekle birlikte, stafilokoklar (S.aureus ve koagülaz negatif stafilokoklar) en sık enfeksiyon etkenidir (Tablo 10). ${ }^{[29]}$ Protez enfeksiyonuna neden olan sınırsız sayıda mikroorganizma vardır ve kültürde kontaminasyon olarak adlandırılan korinebakteriler, propionibakteriler ve Basillus spp. gibi daha birçok bakteri de prostetik eklem enfeksiyonlarına neden olabilir. ${ }^{[29,30]}$ Protez enfeksiyonlarında mantarlar (Genellikle candida olmak üzere aspergillus) ve mikobakteriler (M.tuberculosis ve atipik mikobakteriler) yaygın olmamakla birlikte görülebilir. ${ }^{[29,31,32]}$ Çok nadir olarak listeria, kampilobakterler, Actinomyces spp. ve Gardrenella vaginalis etken olarak bildirilmiştir.[33-35] Prostetik eklem enfeksiyonlarında, özellikle omuz artroplastilerinde son zamanlarda Propionibacterium acnes daha sık görülmeye başlanmıştır. [29]

Tsai ve ark. yaptıkları geriye dönük çalışmada, polimikrobiyal patojenlerin, anaerobların ve enterik gram negatif basillerin kalça protezlerinde diz protezlerine göre daha sık görüldüğünü ifade etmişlerdir. ${ }^{[36]}$ Tümör nekrosis faktör alfa blokerleri (TNF- $\alpha$ ), mikobakteriler ve mantarlar için predispozan bir faktördür ve dissemine histoplasmosis, koksidiomikosis ve blastomikosise neden olabilir. Enflamatuvar/romatoid eklem hastalıkları nedeni ile protez takılan ve TNF blokerleri kullanan hastalarda bu patojenlere bağlı protez enfeksiyonları daha sık oluşacak ve gelecekte mikroorganizmaların dağılımı değişecektir. ${ }^{[29]}$ Zimmerli ve ark.'nın 618 (118 total kalça protezi ve 500 total diz protezi) periprostetik eklem enfeksiyonu olgusundan izole ettikleri mikroorganizmaların oranı S.aureus \%32,8, koagülaz negatif stafilokoklar $\% 26,5$, Streptococcus spp. $\% 8,7$, Enterococcus spp. \%6,6, Propionibacterium spp. \%1,9, gram negatif basil $\% 6,5$, polimikrobiyal $\% 6,1$, üreme olmayanlar $\% 8,9$ ve diğerleri $\% 1,8$ 'dir. ${ }^{[23]}$

Protez enfeksiyonlarında etkenler, enfeksiyonun geliştiği zamana (erken, gecikmiş ve geç) ve etkenin proteze ulaşma yoluna (hematojen, komşuluk ve direkt inoku-

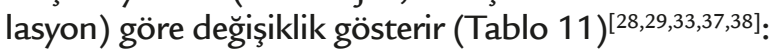

1. Erken (<3 ay) enfeksiyonlarda S.aureus, gram negatif basiller, anaerob bakteriler ve polimikrobiyal etkenler sık görülür. Bunlar virulansı yüksek patojenlerdir. Bakteriler genellikle protez cerrahisi esnasında cerrahi yaraya direkt inokulasyon

Tablo 10. Protez enfeksiyonlarına neden olan mikroorganizmalar ${ }^{[29]}$

\begin{tabular}{lc}
\hline Mikroorganizmalar & Sıklığı (\%) \\
\hline Koagülaz negatif stafilokoklar & 22 \\
\hline S.aureus & 22 \\
\hline Alfa hemolitik streptokoklar (S.viridans) & 9 \\
\hline Beta hemolitik streptokoklar. Grup A, B, G & 5 \\
\hline Enterokoklar & 7 \\
\hline Gram negatif basiller & 25 \\
\hline Anaeroblar & 10 \\
\hline
\end{tabular}


(ameliyathanede havada asılı patojenler, hastanın kendi cildi veya ameliyat personelinin cildindeki patojenlerle kontaminasyon) veya komşuluk (delici travma, aspirasyon, enjeksiyon daha önceden bulunan osteomiyelit, deri ve yumuşak doku enfeksiyonunun yayılımı) yoluyla ulaşır. Protez enfeksiyonlarının çoğu erken dönem enfeksiyonlarıdır.

2. Gecikmiş (3-24 ay) enfeksiyonda, koagülaz negatif stafilokoklar, Propionibacterium acnes, viridans streptokoklar veya enterokoklar daha sık etkendir. Bunlar virulansı düşük patojenlerdir. Bakteriler genellikle protez cerrahisi esnasında cerrahi yaraya direkt inokulasyon yoluyla ulaşır.

3. Geç (>24 ay) enfeksiyonlarda S.aureus, Beta hemolitik streptokoklar veya gram negatif basiller sık görülmektedir. Bunlar da virulansı yüksek patojenlerdir. Bakteriler daha uzaktaki enfeksiyonlardan (üriner, cilt, vasküler kateter vb.) hematojen yolla ulaşır.

Protez enfeksiyonlarının \%20-40'ı hematojen yolla, gerisi direkt bakteri inokulasyonu ile meydana gelir. Hematojen yolla gelişen protez enfeksiyonları çoğunlukla monomikrobiyaldir, S.aureus sıklıkla izole edilen etkendir ve bakterilerin giriş kapısı sıklık sırasına göre cilt, dental, gastrointestinal, üriner ve diğerleri olarak belirlenmiştir. Bu nedenle protez hastalarının ameliyat öncesi hazırlıklarında bu bölgelerde enfeksiyon durumunun araştırılması önemlidir. Protez enfeksiyonları nadiren de kronik osteomiyelit olgularında latent olarak duran bir odağın, protez cerrahisi sırasında dokunun hasarlanmasına bağlı olarak yeniden aktive olmasıyla da gelişebilir. Bu tür olgularda, cerrahi sırasında alınan kültürler steril olmasına rağmen, daha önceden burada var olan S.aureus ve M.tuberculosis enfeksiyonları nüks edebilir. İleriye dönük bir çalışmada S.aureus bakteremisinden sonra \%34 oranında prostetik eklem enfeksiyonu geliştiği bildirilmiştir. Dental öyküleri olan (enfeksiyon, girişim, kırık, kötü hijyen) hastalara konan protezlerde viridans streptokoklara, anaeroblara (Peptococcus, Peptostreptococcus) ve Actinomyces spp. bağlı protez enfeksiyonları geliştiği bilinmektedir. Sellülit gibi pyojenik deri olguları stafilokokal (S.aureus, S.epidermidis) ve streptokokal (Grup A, B, C ve G) protez enfeksiyonlarına neden olabilir. Genitoüriner ve gastrointestinal girişim ya da enfeksiyonlarından sonra gelişen protez enfeksiyonları gram negatif basiller, enterokoklar ve anaerob bakterilerle oluşur. ${ }^{[29]}$ Zeller ve ark.'nın 2018'de yayımladıkları, 997 protez enfeksiyonunundan izole ettikleri mikroorganizmalar ve sıklığı Tablo 12'de verilmiştir. ${ }^{[39]}$

Klinik bulguları olmasına rağmen protez enfeksiyonlarında kültür negatifliği görülebilir. Bu durum enfeksiyon sırasında uzun süre antibiyotik kullanılmasından veya yetersiz bakteriyolojik tetkiklerden kaynaklanabilir. Tedaviye yanıt vermeyen bazı protez enfeksiyonlarında gerçek etken aynı mikroorganizmanın farklı fenotipleri veya koloni varyantları olabilir ve daha ileri bakteriyolojik testler gerektirir. ${ }^{[40]}$

\section{DIYABETIK AYAK ENFEKSIYONLARI}

Diabetes mellituslu hastalarda ayak enfeksiyonu sık görülür ve önemli bir problemdir. Enfeksiyon küçük travmalarla başlar, hafif selülitten, açık ülser, kronik osteomiyelit ve ilerleyici gangrene kadar giden enfeksiyonlar görülebilir.

Tablo 11. Protez enfeksiyonu gelişme zamanına göre etkenler ve proteze ulaşma yolları ${ }^{[28]}$

\begin{tabular}{|c|c|c|}
\hline Enfeksiyonun gelişme zamanı & Mikrobiyolojik etkenler & Ulaşma yolu \\
\hline Erken (<3 ay) & $\begin{array}{l}\text { Virulansı yüksek etkenler } \\
\text { S.aureus, } \\
\text { Gram negatif basiller } \\
\text { Anaerob bakteriler } \\
\text { Polimikrobiyal }\end{array}$ & $\begin{array}{l}\text { Direkt inokulasyon } \\
\text { (havada asılı patojenler, hasta/personel cildi) } \\
\text { Komşuluk } \\
\quad \text { (delici travma, aspirasyon, enjeksiyon, eski kemik, yumuşak doku ve } \\
\text { deri enfeksiyonları) }\end{array}$ \\
\hline Gecikmiş (3-24 ay & $\begin{array}{l}\text { Virulansı düşük etkenler } \\
\text { Koagülaz (-) stafilokoklar } \\
\text { Propionibacterium acne } \\
\text { Streptokoklar/enterokoklar }\end{array}$ & $\begin{array}{l}\text { Direkt inokulasyon } \\
\quad \text { (genellikle protez cerrahisi esnasında) }\end{array}$ \\
\hline Geç (>24 ay) & $\begin{array}{l}\text { Virulansı yüksek etkenler } \\
\text { S.aureus } \\
\text { Beta hemolitik streptokoklar } \\
\text { Gram negatif basiller }\end{array}$ & $\begin{array}{l}\text { Hematojen } \\
\text { (cilt, dental, intestinal, üriner, vasküler kateter vb.) }\end{array}$ \\
\hline
\end{tabular}


Tablo 12. Protez enfeksiyonlarından (n: 997) izole edilen mikroorganizmalar ve sıklığı $(\%)^{[39]}$

\begin{tabular}{|c|c|c|}
\hline Mikroorganizma & $\mathrm{n}$ & $(\%)$ \\
\hline Staphylococcus & 497 & 50 \\
\hline S.aureus & 194 & 19 \\
\hline S.epidermidis & 185 & 19 \\
\hline Diğer koagülaz-negatif Staphylococci & 87 & 9 \\
\hline Miks Staphylococcus enfeksiyon & 31 & 3 \\
\hline Methicillin-resistant Staphylococcus & 216 & 22 \\
\hline S.aureus & 36 & 3,6 \\
\hline Koagülaz-negatif staphylococci & 180 & 18 \\
\hline Streptococcus & 156 & 16 \\
\hline B-hemolytic Streptococcus & 87 & 9 \\
\hline S.agalactiae & 59 & 6 \\
\hline Non-hemolytic Streptococcus & 54 & 5,5 \\
\hline Diğer & 15 & 1,5 \\
\hline Enterococcus faecalis & 27 & 3 \\
\hline Gram-negatif çomaklar & 108 & 11 \\
\hline Enterobacteria & 74 & 7 \\
\hline P.aeruginosa & 25 & 3 \\
\hline Diğerleri & 9 & 1 \\
\hline Anaerobic bacteria & 83 & 8 \\
\hline Propionibacterium spp. & 60 & 6 \\
\hline Diğerleri & 23 & 2 \\
\hline Polymicrobial enfeksiyonlar & 90 & 9 \\
\hline $\begin{array}{l}\text { Diğerleri Corynebacterium spp. } 13 \\
\quad \text { (C.striatum 9, C.jeikeium 2, C.amycolatum 1, C.sp 1) }\end{array}$ & 24 & 2 \\
\hline \multicolumn{3}{|l|}{ Listeria monocytogenes 3} \\
\hline \multicolumn{3}{|l|}{ Mycobacterium tuberculosis 3} \\
\hline \multicolumn{3}{|l|}{ Micrococcus sp 1} \\
\hline \multicolumn{3}{|l|}{ Facklamia hominis 1} \\
\hline \multicolumn{3}{|l|}{ Fungus 3} \\
\hline \multicolumn{3}{|l|}{ (Candida albicans 2, Aspergillus terreus 1 ) } \\
\hline Steril & 12 & 1 \\
\hline
\end{tabular}

Selülit, cilt ve cilt altı dokunun nekrotizan olmayan akut, yaygın enflamasyonudur. S.pyogenes ve S.aureus en sık etkenlerdir. Daha az sıklıkta Haemophilus influenzae, Klostridialar ve Bacillus antracis neden olabilir. Sıklıkla alt ekstremiteler olmak üzere tüm ekstremiteler tutulabilir.

Ülserin geliştiği ve enfeksiyonun kemiğe ilerlediği durumlarda en sık izole edilen bakteriler S.aureus, streptokoklar, enterokoklar, gram negatif barsak bakterileri, Bacteroides spp., Fusobacterium spp. ve diğer anaerob koklardır. Diyabetik ayak enfeksiyonları genellikle polimikrobiyaldir ve anaerobları içerebilir. Yüzeyel, basit sellülit formunda ve ekstremiteyi tehdit etmeyen enfeksiyonlarda monomikrobiyal olabilir. Klinik durumlar ve olası etkenler Tablo 13'de listelenmiştir. ${ }^{[41]}$ Ertuğrul ve ark.'nın yaptıkları çalışmada, en sık saptanan ilk üç mikroorganizma S.aureus, P.aeuriginosa ve E.coli olup gram pozitif etkenlerde artış, gram negatif etkenlerde azalma tespit etmişlerdir. ${ }^{[42]}$ Klinik olarak enfeksiyon düşünülmeyen olgulardan kültür alınmamalıdır. Kültür için yaranın temizlenmesi ve debridmanından sonra derin doku kültürü alınması gerekir. Yüzeyel sürüntü örnekleri yanlış sonuç vereceğinden önerilmez.

\section{NEKROTIZAN FASIiT}

Nekrotizan fasiit, fasyanın da dahil olduğu derin subkutan dokunun ilerleyici nekrozu ile karakterize, çoklu organ yetmezliği ile yaşamı tehdit eden bir enfeksiyon acilidir. Hastanın immunite durumuna göre iki farklı sınıfta incelenmektedir ${ }^{[43]}$ :

Tablo 13. Diyabetik ayak enfeksiyonlarında klinik ve olası etkenler ${ }^{[41]}$

\begin{tabular}{|c|c|}
\hline Klinik & Etken \\
\hline Selülit (açık yara yok) & $\begin{array}{l}\text { Monomikrobiyal } \\
\text { Beta hemolitik streptokok (A, B, C, G grubu) } \\
\text { S.aureus }\end{array}$ \\
\hline Yeni gelişmiş enfekte ülser (antibiyotik kullanımı yok) & $\begin{array}{l}\text { Sıkklıkla monomikrobiyal } \\
\text { S.aureus } \\
\text { Beta hemolitik streptokok (A, B, C, G grubu) }\end{array}$ \\
\hline Kronik enfekte ülser (öncesinde antibiyotik kullanımı var) & $\begin{array}{l}\text { Genellikle polimikrobiyal } \\
\text { S.aureus } \\
\text { Beta hemolitik streptokok (A, B, C, G grubu) } \\
\text { Gram negatif enterik bakteriler }\end{array}$ \\
\hline Mavi-yeşil pürülan akıntı var & P.auriginosa \\
\hline Geniş nekroz veya gangren, kötü kokulu akıntı & $\begin{array}{l}\text { Genellikle polimikrobiyal } \\
\text { Aerob gram pozitif kok (S.aureus, koagülaz negatif stafilokoklar, enterokok) } \\
\text { Gram negatif enterik bakteriler } \\
\text { Pseudomonas spp. } \\
\text { Acinetobater spp. } \\
\text { Anaerob bakteriler }\end{array}$ \\
\hline Sağlık bakımı ile ilişkili & Metisilin dirençli S.aureus, geniş spectrumlu beta-laktamaz üreten gram negatif çomaklar \\
\hline
\end{tabular}




\section{Tip 1 (Polimikrobiyal Enfeksiyon)}

En az bir anaerob olmak üzere (En sık Bacteroides, Clostridium veya peptostreptokok) bir veya daha fazla gram pozitif aerob (Streptokoklar, enterokoklar) ve gram negatif aerob basillerin (Escherichia, Enterobacter, Klebsiella, Proteus vb.) birlikte bulunması ile gelişir. Sıklıkla diyabet gibi altta yatan kronik bir hastalığı olanlarda veya cerrahi sonrası gelişir.

\section{Tip 2 (Grup A Streptokokal Enfeksiyon)}

Grup A streptokoklar en sık görülen etkendir. "Et yiyen bakteri" olarak da tanımlanır. Grup A streptokoklar veya diğer beta hemolitik streptokoklar tek başına veya diğer etkenlerle (En sık S.aureus) beraber olabilir. Sağlıklı kişilerde de görülebilir. Yaralanma, ince kesikler veya cerrahi, künt travmalar, yanık, varisella enfeksiyonları, kaynak olgu ile yakın temas ve i.v. madde bağımlılı̆ı predispozan faktörlerdir.

\section{MiYoziT}

Kasın nadir görülen ve genellikle nedeni belli olmayan enflamatuvar hastalıkları olan miyozitler, mikroorganizmalar etken olduğunda enfeksiyöz miyozit adını alır. Etkenler, komşuluk yoluyla (deri veya derialtı abse, derin yaralanma, dekubitis ülserleri, osteomiyelit) veya hematojen yolla kasa ulaşır. Bunlar, piyojenik, nonpiyojenik, lokalize ve jenaralize olabilir (Tablo 14). ${ }^{[4]}$

\section{Gazlı Gangren (Klostridyal Miyonekroz)}

Çizgili kasları tutan, çok hızlı ilerleyen, hayati tehlikesi olan enfeksiyon acillerindendir. Olguların \%80-95'inde etken normal kolon florasında bol miktarda bulunan Clostridium perfringens'dir. Diğer etkenler C.novyi (\%1040), C.septicum (\%5-20), C.bifermentas, C.histolyticum, C.fallax, C.ramosum, C.sordelii olabilir.

Clostridium perfringens, post travmatik olarak toprak ve yabancı cisim içeren kirli penetran yaralar (kaza, savaş), cerrahi yaralar (özellikle barsak ve safra sistemi), septik düşükler ve ekstremitelerde gelişen arteriyel yetersizlik durumlarında etkendir. Nadiren bazı parenteral ilaçlardan sonra ve garanülositopenik hastalarda rutin venöz uygulamalar sonrası oluşabilir. Clostridium septicum, nontravmatik-spontan olarak kolon kanseri, divertikülit, barsak infarktı, nekrotizan enterokolit, volvulus gibi genellikle intestinal hastalıklar durumunda etkendir.

\section{Psoas Absesi}

Etken bakteri, hastalığın kaynağı ile ilgilidir. Vertebral osteomiyelite sekonder ise S.aureus veya M.tuberculosis, intestinal enfeksiyon sonrası ise aerobik ve anaerobik barsak florası, çocuklarda hematojen yolla geliştiyse S.aureus'dur.

Tablo 14. Miyozitlerin sınıflaması ve en sık görülen etken mikroorganizmalar ${ }^{[44]}$

\begin{tabular}{lll}
\hline Miyozitin Tipi & Klinik & Etkenler \\
\hline Piyojenik & 1. Piyomiyozit & S.aureus, Grup A streptokoklar, Gram negatif basiller \\
ve & 2. Gazlı gangren & Clostridium perfringens ve diğer histotoksik clostridiumlar \\
& 3. Nonklostridyal miyozit & Peptostreptokoklar \\
& Anaerobik streptokokal gangren & Grup A streptokoklar \\
& Sinerjistik anaerobik miyonekroz & Miks enfeksiyonlar, \\
& Enfekte vasküler gangren & Bacteroides, Peptostreptokoklar, \\
& Aeromonas hydrophila miyonekrozu & Streptokoklar, E.coli, Klebsiella, Enterobacter \\
& 4. Psoas apsesi & Sinerjistik anaerobik miyonekroz ile aynı etmenler \\
& & A.hydrophila \\
Nonpiyojik & & Gram negatif basiller, S.aureus, miks enfeksiyonlar \\
ve & 1. Miyaljiler & M.tuberculosis \\
\hline 2. Plorodini & Viral enfeksiyonlar (influenza, dengue), enfektif \\
endokardit, bakteremiler (meningokoksemi), riketsiyozlar & (Rocky Mountain ateşi), toksoplasmosis
\end{tabular}




\section{KAYNAKLAR}

1. Christophera OHI. Infectious arthritis of native joints. In: Bennett JE, Dolin R, Blaser MJ, editors. Mandell, Douglas, and Bennett's Principles and Practice of Infectious Diseases. Philadelphia: Elsevier; 2017. p.1400-17.

2. Ross JJ. Septic arthritis of native joints. Infect Dis Clin North Am 2017;31(2):203-18. Crossref

3. Arnold SR, Elias D, Buckingham SC, Thomas ED, Novais E, Arkader A, Howard C. Changing patterns of acute hematogenous osteomyelitis and septic arthritis: Emergence of community-associated methisilin-resistant Staphylococcus aureus. J Pediatr Orthop 2006;26(6):703-8. Crossref

4. Arnold JC, Bradley JS. Osteoarticular infections in children. Infect Dis Clin North Am 2015;29(3):557-74. Crossref

5. Öktem A, Çelik HT, Göçer E, Ceyhan M, Yiğit Ş, Yurdakök M. Yenidoğan döneminde septik artrit ve osteomiyelit: Deneyimlerimiz ve güncel bilgilerin gözden geçirilmesi. Çocuk Sağ|ı̆̆ı ve Hastalıkları Derg 2016;56:1-13. http://www.cshd. org.tr/uploads/pdf_CSH_1524.pdf

6. Dubnov-Raz G, Scheuerman O, Chodick G, Finkelstein Y, Samra Z, Garty BZ. Invasive Kingella kingae infections in children: Clinical and laboratory characteristics. Pediatrics 2008;122(6):1305-9. Crossref

7. Rice PA. Gonococcal arthritis (disseminated gonococcal infection). Infect Dis Clin North Am 2005;19(4):853-61. Crossref

8. Schelenz S, Bramham K, Goldsmith D. Septic arthiritis due to extended spectrum beta lactamase producing Klebsiella pneumoniae. Joint Bone Spine 2007;74(3):275-8. Crossref

9. Hogan JI, Hurtado RM, Nelson SB. Mycobacterial musculoskeletal infections. Thorac Surg Clin 2019;29(1):8594. Crossref

10. Bariteau JT, Waryasz GR, McDonnell M, Fischer SA, Hayda RA, Born CT. Fungal osteomyelitis and septic arthritis. J Am Acad Orthop Surg 2014;22(6):390-401. Crossref

11. Shmagel A, Skemp-Dymond G, Langsetmo I, Schousboe JT, Ensrud K, Foley R. Population- wide associations between common viral pathogenes and self-reported arthritis: NHANES 2009-2012. Int J Rheumatol 2018;1-7. Crossref

12. Ulutan F, Taş N. Reaktif artritler. İçinde: Topçu AW, Söyletir G, Doğanay M, editörler. Enfeksiyon Hastalıkları ve Mikrobiyolojisi. İstanbul: Nobel Kitabevleri; 2008. p.1351-3.

13. Tande AJ, Steckelberg JM, Osmon DR, Berbari EF. Osteomyelitis. In: Bennett JE, Dolin R, Blaser MJ, editors. Mandell, Douglas, and Bennett's Principles and Practice of Infectious Diseases. Philadelphia: Elsevier; 2017. p.1418-30.

14. Çiftdoğan DY. Akut komplike olmayan septik artrit ve osteomiyelit epidemiyolojisi ve yönetimi: Çok Merkezli İspanyol Çalışması. J Pediatr Inf 2017;11(1):58-9. Crossref

15. Ulutan F, Şenköylü A, Bölükbaşı S. Osteomiyelit. İçinde: Topçu AW, Söyletir G, Doğanay M, editörler. Enfeksiyon Hastalıkları ve Mikrobiyolojisi. İstanbul: Nobel Kitabevleri; 2008. p.1363-9.

16. Zimerli W, Flückiger U. Classification and microbiology of osteomiyelitis. Orthopade 2004;33(3):267-72. Crossref

17. Garcia Del Pozo E, Collazos J, Carton JA, Camporro D, Asensi V. Bacterial osteomyelitis: microbiyological, clinical, threrapeutic, and evolituve characteristics of 344 episodes. Rev Esp Quimioter 2018:31(3);217-25. https://www.ncbi. $\mathrm{nlm}$.nih.gov/pmc/articles/PMC6166254/

18. Kandemir Ö. Osteomiyelit. İçinde: Kurt H, Gündes S, Geyik MF, editörler. Enfeksiyon Hastalıkları. İstanbul: Nobel Kitabevleri; 2016. p.389-92.
19. Yagupsky P. Microbiological diagnosis of skeletal system infections in children. Curr Pediatr Rev 2019;15(3):154-63. Crossref

20. Bocchini CE, Hulten KG, Mason EO Jr, Gonzalez BE, Hammerman WA, Kaplan SL. Panton-Valentine leukocidin genes are associated with enhanced inflammatory response and local disease inacute hematogenous Staphylococcus aureus osteomyelitis in children. Pediatrics 2006;177(2):43340. Crossref

21. Fily F, Ronat J-B, Malou N, Kanapathipillai R, Seguin C, Hussein N, Fakhri R and Langendorf C. Post-traumatic osteomiyelitis in Middle East war-wounded civilians: resistance to first-line antibiotics in selected bacteria over the decade 2006-2016. BMC Infect Dis 2019;19(1):103. Crossref

22. Metsemakers WJ, Kuehl R, Moriarty TF, Richards RG, Verhofstad MHJ, Borens O, Kates S, Morgenstern M. Infections after fracture fixation: current surgical and microbiological concepts. Injury 2018;49(3):511-22. Crossref

23. Zimmerli W, Sendi P. Orthopaedic biofilm infections. APMIS 2017;125(4):353-64. Crossref

24. Brook I. Microbiology and management of joint and bone infections due to anaerobic bacteria. J Orthop Sci 2008;13(2):160-9. Crossref

25. Beratta-Piccoli BC, Sauvain MJ, Gal I, Schibler A, Saurenmann T, Kressebuch H, Bianchetti MG. Synovitis, acne, pustulosis, hyperostosis, osteitis (SAPHO) syndrome in childhood: A report of ten cases and review of the literature. Eur J Pediatr 2000;159(8):594-601. Crossref

26. Becker A, Triffault-Fillit, Valour F, Boussel L, Ruffion A, Laurent F, Senneville E, Chidiac C, Ferry T. Pubic osteomyelitis: Epidemiology and factors with treatment failure. Med Mal Infect 2019;S0399-077X(19)31064-9. Crossref

27. Wylie SC, Cullum C, Brarens B. Considerations in the diagnosis and management of lower- extremity infections heroin users. J Am Podiatr Med Assoc 2019;109(6):437-44. Crossref

28. Kayabas Ü. Protez enfeksiyonları. İçinde: Kurt H, Gündes S, Geyik MF, editörler. Enfeksiyon Hastalıkları. İstanbul: Nobel Kitabevleri; 2016. p.393-7.

29. Zimmerli W, Sendi P. Orthopedic implant-associated infections. In: Bennett JE, Dolin R, Blaser MJ, editors. Mandell, Douglas, and Bennett's Principles and Practice of Infectious Diseases. Philadelphia: Elsevier; 2017. p.1430-42.

30. Noussair L, Salamon E, El Sayed F, Duran C, Bouchand F, Roux AL, Gaillard JL, Bauer T, Rottman M, Dinh A. Monomicrobial bone and joint infection due to Corynebacterium striatum: Literature review and amoxicillin-rifampin combination as treatment perspective. Eur J Clin Microbiol Infect Dis 2019;38(7):1269-78. Crossref

31. Sigler R, Newman JR. Mycobacterium Avium Prosthetic Hip Infection on Abatacept Presenting as Fever of Unknown Origin. J Bone Joint Infect 2019;4(4):194-7. Crossref

32. Nengue L, Diaz MAA, Sherman CE, Bhasin A, Libertin CR. Mycobacterium abscessus prosthetic joint infections of the knee. J. Bone Joint Infect 2019;4(5):223-6. Crossref

33. Arısoy A. Kemik ve eklemlerin protez enfeksiyonları. İçinde: Topçu AW, Söyletir G, Doğanay M, editörler. Enfeksiyon Hastalıkları ve Mikrobiyolojisi. İstanbul: Nobel Kitabevleri; 2008. p.1363-9.

34. Dagher R, RiazT, Tande AJ, Osmon DR, Jagtiani A, Steckelberg JM, Mabry T, Berbari EF. Prosthetic joint infection due to Actinomyces specis: A case series and review of literature. J Bone Joint Infect 2019;4(4):174-80. Crossref 
35. Thomas M, Zeller V, Heym B, Meyssonnier V, Marmor S, Ziza JM. Gardnerella vaginalis, from the vaginal microbiota to prosthetic joint infection. J Bone Joint Infect 2019;4(4):18993. Crossref

36. Tsai Y, Chang CH, Lin YC, Lee SH, Hsieh PH, Chang Y. Different microbiological profiles between hip and knee prosthetic joint infections. J Orthop Surg 2019;27(2):230949901984776. Crossref

37. Zimmerli W. Clinical presentation and treatment of orthopaedic implant-associated infection. J Intern Med 2014;276(2):111-9. Crossref

38. Parvizi J, Zmistowski B, Berbari EF, Bauer TW, Springer BD, Della Valle CJ, Garvin KL, Mont MA, Wongworawat MD, Zalavras CG. New definition for periprosthetic joint infection: from the Workgroup of the Musculosceletal Infection Society. Clin Orthop Relat Res 2011;469(11):2992-4. Crossref

39. Zeller V, Kerroumi Y, Meyssonnier V, Heym B, Metten M-A, Desplaces N, Marmor S. Analysis of postoperative and hematogenous prosthetic joint infection microbiological patterns in a large cohort. J Infect 2018;76(4):328-34. Crossref
40. Gül CG, Artuk C, Yıldız C. The Diagnosis, treatment and management of prosthetic joint infections. J Clin Anal Med 2013;4(4):332-9. Crossref

41. Lipsky BA. Diagnosing and treating diabetic foot infections. Klimik Derg 2009;22(1):2-13. https://www.klimikdergisi. org/content/files/sayilar/11/buyuk/2-13.pdf

42. Ertuğrul MB, Uyar-Güleç G, Baktıroğlu S, Çörekli E, Türe M. Diyabetik ayak enfeksiyonu etkenlerinin yıllara göre dağılımı: Değişim var mı? Klimik Derg 2017;30(1):27-31. Crossref

43. Akalın Ş. Nekrotizan fasiit. İçinde: Kurt H, Gündeş S, Geyik MF, editörler. Enfeksiyon Hastalıkları. İstanbul: Nobel Kitabevleri; 2016. p.372-4.

44. Pasternack MS. Myositis and myonecrosis. In: Bennett JE, Dolin R and Blaser MJ, editors. Mandell, Douglas, and Bennett's Principles and Practice of Infectious Diseases. Philadelphia: Elsevier; 2017. p.1306-17. 